Aсп. Д.В. Каньовська

Postgraduate D.V. Kano'vska

\title{
УДОСКОНАЛЕННЯ СТРУКТУРИ ІНФОРМАЦЙНО-КЕРУЮЧОӤ СИСТЕМИ МІСЦЕВОЇ РОБОТИ ЗАЛІЗНИЧНОГО ТРАНСПОРТУ
}

\section{THE IMPROVEMENT OF INFORMATIONAL-MANAGING SYSTEMS OF LOCAL WORK OF RAILWAY TRANSPORT}

\author{
Представив д-р техн. наук, професор Т.В. Бутько
}

Вступ. Сучасні процеси реформування транспортної галузі України впливають та викликають зміни у всіх сферах економіки держави. Це істотно відбивається на процесах взаємодії залізничного транспорту загального, незагального користування та підприємстввантажовідправників. Гармонічний розвиток цієї системи створює умови для успішного комплексного і пропорційного розвитку промислових підприємств та економіки цілих регіонів. Таким чином, технологію обробки вантажів залізничним транспортом на початковому етапі перевезення пов'язано з тим, що, по-суті, транспортування $є$ продовженням процесу виробництва та істотно впливає на промислові підприємства-відправники, особливо в умовах великої географічної розпорошеності виробництва.

Постановка проблеми. Однією 3 важливих умов до забезпечення прибутковості і конкурентоспроможності залізничного транспорту у складі єдиної транспортно-логістичної системи $\epsilon$ формування цілісної структури його управління 3 метою реалізації сучасних логістичних технологій доставки вантажів. Отримати синергетичний загальносистемний ефект від своєчасної доставки вантажів можливо тільки в умовах використання сучасних інформаційнокеруючих систем (IКC) на базі логістичних принципів $[1,2]$. 
В умовах значних коливань вантажопотоків, територіальної розпорошеності виробників та конкуренції 3 іншими видами транспорту одним 3 шляхів прискорення доставки вантажів 3 мінімальними експлуатаційними витратами $\epsilon$ впровадження технології з використанням вантажного автономного збірного поїзда (ВАЗП) для обробки та просування місцевих вагонопотоків. Тому виникає науково-прикладна задача формування структури ІКС місцевою роботою, яка передбачає не тільки удосконалення існуючих, але і створення нових технологій роботи залізничного транспорту при взаємодії із станціями примикання, під'їзними коліями промислових підприємств та місцями загального користування на станціях 3 невеликими обсягами роботи. В першу чергу це актуально в умовах обслуговування цілісних залізничних полігонів, таких як дирекція (ДН) або диспетчерська дільниця, 3 наявністю місцевих вантажів. Як показує світовий досвід, в цих умовах ефект від використання IКС найбільш вагомий i настає через невеликий час після впровадження.

Аналіз досліджень і публікацій. Магістральний залізничний транспорт в Україні повинен якнайшвидше здійснити впровадження нових логістичних технологій [3]. Процес реалізації на транспорті логістичних технологій безперервно пов'язаний 3 автоматизацією усіх ланок транспортно-логістичної системи $[4,5]$ та 3 впровадженням IКС та систем підтримки прийняття рішень (СППР) 3 метою отримання загальносистемного ефекту [6, 7]. Застосування логістичних технологій для прискорення просування місцевих вагонопотоків спрямовано на отримання оптимальних рішень у транспортному процесі [1, 8]. У світі використовують технологію роботи 3 місцевими вантажопотоками 3 високим ступенем автономності - концепція, яку розроблено німецькою компанією Windhoff, a саме вантажний дизель-поїзд Cargo Sprinter [9]. Але у Німеччині, Австрії, Великобританії та інших країнах, що його використовують, вантажопотік у місцевому сполученні не має такого великого коливання, як в Україні. Тому необхідно врахувати усі особливості вітчизняного транспортного ринку шляхом впровадження вантажного автономного збірного поїзда.

Формування ІКС для ефективної реалізації технології 3 ВАЗП повинно базуватись на сучасних математичних методах i підходах 3 використанням елементів штучного інтелекту в АРМ оперативного персоналу $[10,11]$.

Удосконалення структури інформаційно-керуючої системи місцевою роботою залізничного транспорту. Аналіз технологій роботи підприємстввантажовідправників показує наявність двох основних варіантів обслуговування залізничним транспортом місцевих вантажопотоків:

I. Промислові підприємства безпосередньо виконують обслуговування вантажів на місцях загального користування залізничної станції. Особливість задач та функцій ІКС місцевої роботи при цьому полягає в тому, що станція самостійно здійснює управління маневровою, ватажною та комерційною роботою. Оскільки цей сегмент ринку $\epsilon$ найбільш конкурентним із іншими видами транспорту, пропонується створення на станції місцевого логістичного центру (МЛЦ). На кожній станції, на якій є МЛЦ, засобами вантажно-розвантажувальних машин, що слідують у складі ВАЗП, виконуються вантажні операції 3 вантажами.

II. До магістральної залізничної станції примикає технологічна ланка у вигляді під'їзної колії підприємства або підприємство має вантажні площі на станції і доставку вантажів до них здійснює за допомогою автотранспорту. Найбільш ефективне використання складних 
високопродуктивних

вантажно-

розвантажувальних машин та маневрових засобів в цих умовах забезпечується шляхом створення окремих потужних опорних логістичних центрів (ОЛЦ), в яких зосереджена така техніка. В цьому випадку IКС місцевої роботи повинна включати до себе додаткові задачі, які дозволять раціонально використовувати рухомий склад у процесі його розподілу по фронтах навантаження ОЛЦ, прискорювати обробку вантажопотоку та інформації на початковій та кінцевій стадіях перевізного процесу, раціонально планувати виконання маневрової роботи та забезпечити прийняття рішень 3 прискорення просування матеріального потоку у процесі інформаційної взаємодії із автоматизованою системою керування вантажними перевезеннями (АСК ВП УЗ Є).

Існуюча інформаційна база може стати основою створення ІКС місцевою роботою у вигляді комплексних АРМ на базі СППР та їх інтеграції 3 існуючими автоматизованими системами суміжних служб - системи АС МЕСПЛАН, АРМ ТВК, АРМ прийомоздавальника, АC ЛОКБРІГ, розвиток яких здійснюється шляхом більш тісної інтеграції до АСК ВП УЗ 6.

Попередні дослідження та аналіз технологій виконання місцевої роботи свідчать про наявність потенціалу щодо скорочення часу знаходження вантажних вагонів на під’їзних коліях та місцях загального користування за рахунок реалізації удосконаленої технології роботи та створення IКС. На рис. 1 наведено розподіл складових елементів обігу вагона по елементах для залізниць України. Аналіз даних показує, що 44,4 \% обігу вагона на Укрзалізниці припадає на знаходження вагонів на станціях під вантажними операціями. Показники роботи Харківської дирекції залізничних перевезень доводять, що близько 58\% від цього часу місцевий вагон простоює в міжопераційному очікувані, тобто непродуктивно.

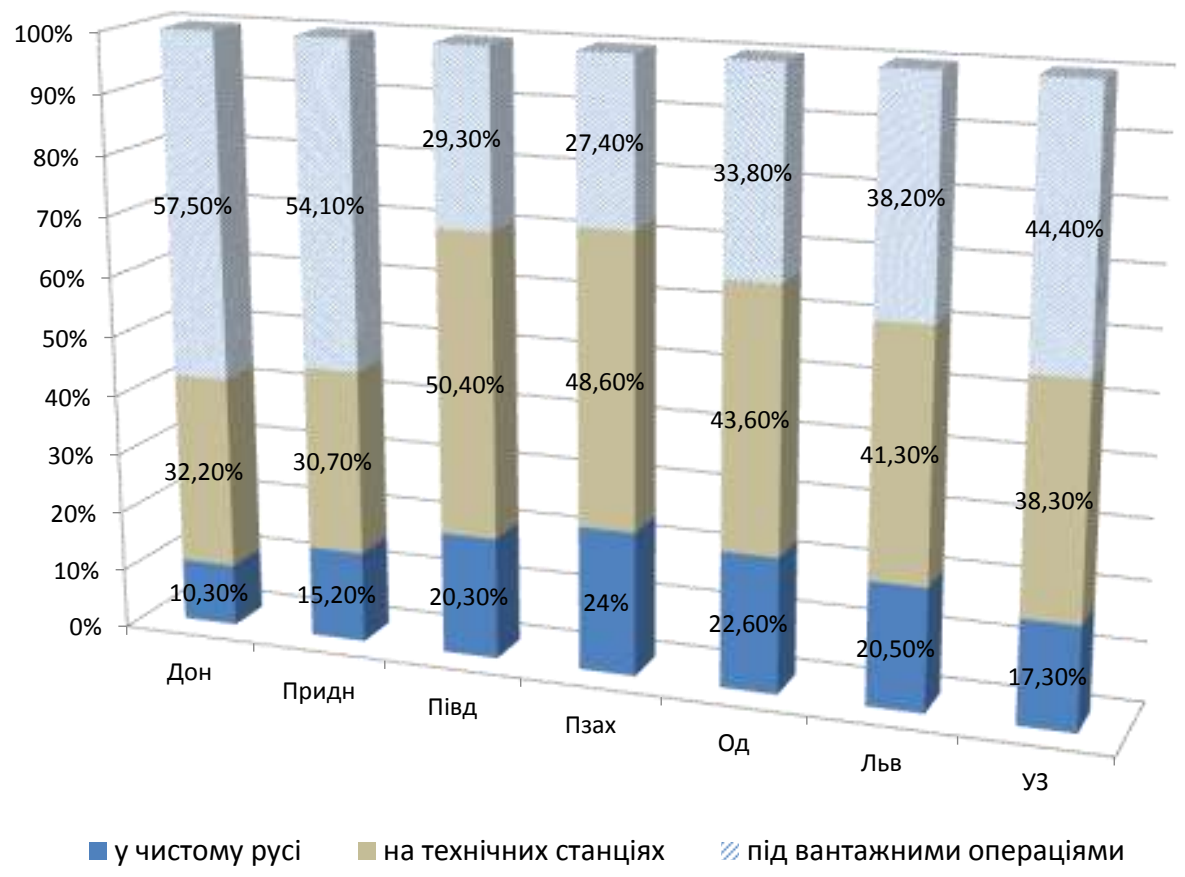

Рис. 1. Розподіл складових елементів обігу вагона по залізницях України 
Існуючу структуру управління місцевою роботою розглянемо на прикладі Харківської дирекції залізничних переве- зень (ДН-2, рис. 2) Південної залізниці як одного 3 характерних та складних за структурою полігонів на Укрзалізниці.

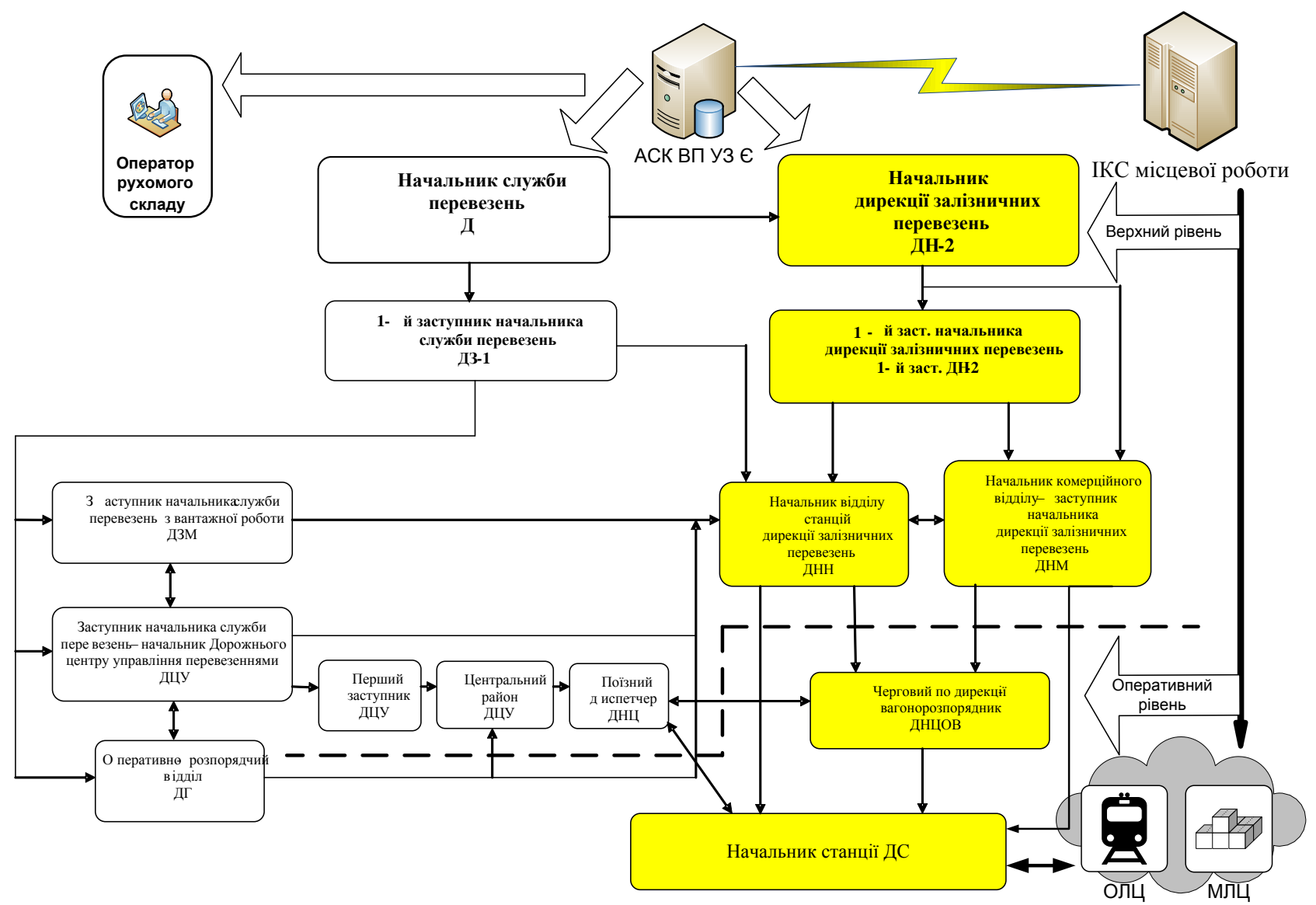

Рис. 2. Структурна схема управління існуючою технологією обробки місцевого вантажу на ДН-2 Південної залізниці

Робота 3 місцевими вагонами за послідовністю виконання операцій містить передачу i розвіз місцевого вантажу; перерозподіл порожніх вагонів; операції 3 місцевими вагонами на станції вивантаження - подавання вагонів до місць вивантаження i процес вивантаження вагонів, включно в необхідних випадках i очищення вагонів після їх розвантаження. Загальний час, який витрачається на виконання операцій впливає на час обігу місцевого вагона. Істотний вплив на технологію місцевої роботи з вантажами дають максимальні та мінімальні рівні навантаження i вивантаження на кожній станції, добова нерівномірність вагонопотоків.

Місцеві вагони, які знаходяться на дирекції, діляться на вагони, які підлягають до передачі на інші дирекції та залізниці та підлягають розвозу та вивантаженню на станціях дирекції у складі ВАЗП. Порожні вагони, які вивільнюються після вивантаження, або використовуються під навантаження, або направляються для здавання за регулювальним завданням.

Підвищення продуктивності вантажного вагона отримується за рахунок скорочення непродуктивних міжопераційних простоїв у процесі раціонального 
планування вантажної роботи на добу, розробки і суворого дотримання графіка руху ВАЗП. Прискорення обігу місцевого вагона на полігоні реалізовано за рахунок оптимізації виконання технологічних операцій шляхом удосконалення нормативів 3 обробки вагонів та забезпеченням через АРМ поопераційного контролю за технологією місцевої роботи.

$$
\text { Місцева робота полігона }
$$
організовується на основі плану, який передбачає виконання завдання на навантаження i вивантаження за раціональною схемою, що передбачає мінімальні простої місцевих та пробіги порожніх вагонів, найбільш економічне використовування локомотивів. Це досягається шляхом використання технікоекономічного моделювання роботи в складі СППР на АРМ оперативних працівників. При розробці плану організації місцевої роботи враховується нерівномірність навантаження за окремими днями, 3 урахуванням якої формується раціональна схема обслуговування та траєкторія руху ВАЗП на полігоні. Показники вантажної роботи встановлюються начальником відділу станцій дирекції 3 урахуванням оперативного завдання на навантаження i вивантаження, які регламентують для кожних станцій, ОЛЦ, МЛЦ та відправників вантажу.

Планування навантаження вагонів для ВАЗП встановлюють згідно 3 технічним та державним планами навантаження, на підставі заявок вантажовідправників через АC МЕСПЛАН та наявності та надходження порожніх вагонів заступником начальника відділу перевезень або черговим вагонорозпорядником (ДНЦОВ) на добу із зазначенням навантаження за родом вантажів. Штат ДНЦОВ складається 3 одного змінного вагонорозпорядника на правах чергового по дирекції, якому підпорядковується черговий станційний диспетчерський апарат, що пов'язаний єдиною технологією місцевої роботи у межах обертання ВАЗП $з$ підв'язкою роботи поїзних локомотивів - на дільницях та маневрових - на станціях. Вихідними даними для складання плану вивантаження $\epsilon$ :

- передбачувана наявність вагонів на станціях вивантаження до початку доби, на яку розробляється план;

- передбачувана наявність місцевого вантажу на МЛЦ та ОЛЦ;

- дані з АСК ВП УЗ С про кількість вагонів, яку планується навантажити в адрес станцій дирекції з інших полігонів i які повинні бути вивантажені в добу, на яку розроблюється план;

- передбачуване надходження місцевого вантажу 3 інших залізниць та дирекцій.

Для зменшення простоїв під вантажними операціями і зменшення порожнього пробігу в ІКС місцевої роботи передбачено використання вагонів після вивантаження під здвоєнні операції на підприємствах, що знаходяться у районі тяжіння станції вивантажування. Якщо такої потреби немає, то вагони використаються під багатократні вантажні операції у межах дільниці обслуговування або на дирекції.

Планування розвозу місцевого вантажу виконується у вигляді планрозвозу місцевого вантажу ВАЗП, який складається черговим ДНЦОВ 3 урахуванням рекомендацій СППР відповідного АРМ на підставі встановленого графіка руху поїздів, наявності місцевого вантажу на сортувальних, дільничних станціях, ОЛЦ та МЛЦ полігону, а також 3 урахуванням підготовлених до відправлення вагонів 3 місцевим вантажем 3 наявними готовими перевізними документами. 3 метою підвищення якості планування перевезень вантажів по станціях дирекції планування здійснюється в умовах застосування автоматизованої системи АС МЕСПЛАН та електронного перевізного документу. Введення замовлення в АС МЕСПЛАН забезпечується на рівні надання замовлення 
кожним вантажовласником у процесі інформаційної взаємодії 3 ІКС місцевої роботи полігона.

Для своєчасного формування автоматизованого звіту ДСП станції, на яку прибув ВАЗП, вводить в АРМ ДСП інформацію про прибуття поїзда на станцію (повідомлення 201) з усіма даними, далі вводиться інформація про відчеплення або причеплення вагонів (повідомлення 09), при необхідності вводиться інформація про розформування (повідомлення 203) складу поїзда на станції. Після прибуття на станцію та після подачі вагона на під’їзну колію прийомоздавальник через свій АРМ вводить інформацію про подавання вагонів на під'їну колію, а в систему АСК ВП УЗ С автоматично формується повідомлення 1397. Товарний касир у АРМ ТВК виконує всі технологічні операції 3 оформлення навантаження або вивантаження вагона та перевірку електронного перевізного документа, таксировку, друкування та фіксує час приймання вантажу до перевезення.

При відправленні ВАЗП зі станції ДСП формує телеграму-натурний лист (ТГНЛ, повідомлення 02) і фіксує цю інформацію в АРМ ДСП із зазначенням часу відправлення поїзду. Дані передаються до ІКС місцевої роботи i використаються для оперативного корегування плану роботи ВАЗП.

Виходячи 3 цього структура та функції ІКС місцевої роботи повинні бути спрямовані на вирішення задач удосконалення технології взаємодії станцій, підприємств-вантажовласників та ïx під'їзних колій у процесі виконання вантажних операцій i транспортування вантажів на базі системи місцевих та опорних логістичних центрів. Для реалізації логістичних технологій роботи ВАЗП запропоновано кожний варіант ІКС побудувати за модульним принципом. Методологія побудови ІКС місцевої роботи повинна базуватися на об'єднанні можливостей системи АСК ВП УЗ $Є$ за рахунок розширення комплексу задач, впровадження безпаперового обміну даними та електронного підпису, уніфікації формату повідомлень із міжнародними стандартами обміну логістичною інформацією. Основою для формування технологічних модулів ІКС місцевої роботи повинен стати комплекс моделей роботи ВАЗП в умовах формування мережі ОЛЦ та МЛЦ. Окрему складність викликає інформаційна взаємодія із вагонною та локомотивною моделями АСК ВП УЗ $€$, особливо в частині автоматизованого визначення дислокації і стану рухомого складу. В той же час, як централізована система, верхній рівень ієрархії ІКС місцевої роботи на полігоні (АРМ ДНН або ДНЦОВ) при застосуванні ВАЗП визначає параметри просування транспортного потоку, якими повинен керуватися нижній рівень ІКС - на рівні АРМ ДНЦ, ДСП, ОЛЦ, МЛЦ та клієнта на підприємстві.

Підсистема управління місцевою роботою верхнього рівня повинна виконувати такі основні функції:

- прийняття рішення щодо здійснення керуючого впливу на перевізний процес у ВАЗП у процесі виконання плану та оцінки відхилення від нього;

- контролю просування місцевого вагонопотоку в умовах дотримання норм на виконання технологічних операцій iз окремими вагонами та на повернення порожнього рухомого состава власникам за узгодженням 3 операторами рухомого складу;

- формування прогнозу зміни оперативної ситуації на полігоні 3 урахуванням даних АСУ ВП УЗ $€$ та роботи на під'їзних коліях, уточнення планових обсягів вивантаження i відправлення порожніх вагонів;

- реалізації та контролю виконання плану розвозу вантажу та порожніх вагонів під навантаження ВАЗП по станціях, ОЛЦ, МЛЦ та на окремих під'їзних коліях підприємств; 
- формування даних про перевізний процес на полігоні та формування необхідних інформаційних повідомлень для АСК ВП УЗ з виконання плану місцевої та вантажної роботи, виконання показників експлуатаційної роботи.

До функцій підсистеми оперативного планування, контролю та аналізу місцевої роботи ВАЗП запропоновано віднести:

- оперативний контроль i аналіз процесу перевезення на полігоні обслуговування ВАЗП та під'їзних коліях підприємств (за їх наявності), моніторинг дотримання термінів доставки при взаємодії зі станцією примикання;

- економічну оцінку варіантів оперативного плану організації роботи ВАЗП в режимі реального часу за допомогою СППР 3 порівнянням його 3 базовим варіантом.

- технологічну оцінку варіантів планів місцевої роботи та аналіз результатів прийняття управлінських рішень за фактичними витратами;

- контроль дотримання умов роботи iз рухомим складом (окремо - загального парку, власного та орендованого, інших держав), врахування та узгодження умов навантаження із операторами рухомого складу;

- формування раціонального пономер-ного плану призначення вагонів із прикріпленням їх до ВАЗП і бригад прийомоздавальників.

На рис. 3 показана удосконалена схема інформаційних логістичних потоків щодо перевезень місцевих вантажів за участю ВАЗП за визначеним вище варіантом 1 при формуванні МЛЦ. До недоліків даної структури ІКС місцевої роботи можливо віднести обробку обмеженої кількості стандартної інформації 3 АСК ВП УЗ в АРМ ТВК та АС МЕСПЛАН, а також відсутність безпосередньої інформаційної взаємодії 3 операторами рухомого складу.
Пояснення до рис. 3:

інформаційний потік (1) - обмін даними про відправки, вантажі та вагони між АСК ВП УЗ $Є$ та АРМ ДНН, ДНЦВ, ДСП і ТВК. Інформація складається 3 iз автоматично згенерованих відповідей та повідомлень ІКС місцевої роботою;

інформаційний потік (2) - обмін повідомленнями про відправки та вантажі між АСК ВП УЗ та АРМів ТВК і АC МЕСПЛАН. Обробка інформації після вхідного логічного контролю складається із запису повідомлення в базу, пересилання іiі до АСК ВП УЗ, генерації відповіді і відсилання відповіді назад до ТВК. За необхідністю здійснюється оперативна взаємодія із іншими АРМ;

інформаційний потік (3) - обмін оперативними технологічними повідомленнями про вагони та вантажі між АРМ ДНН (ДНЦОВ) та АРМ працівника ДСП (МЛЦ). При цьому здійснюється логічний контроль 3 використанням плану місцевої роботи ВАЗП, замовлень АРМ ТВК та відповідей підсистеми створення раціонального режиму місцевої роботи на полігоні;

інформаційний потік (4) - обмін повідомленнями АРМ ТВК на відправки, вагони і вантажі (повідомлення 09, 1397) та узгоджені з АСК ВП УЗ $Є$ та операторами рухомого складу відповіді ІКС місцевої роботи;

інформаційний потік (5) - обмін відповідями АРМ клієнта (АС МЕСПЛАН) 3 ІКС місцевої роботи. При цьому використовується інформація та формат стандартних повідомлень АСК ВП УЗ Є;

інформаційний потік (6) - єдине інформаційне середовище ІКС місцевою роботою та СППР на базі повідомлень системи.

На схемі, наведеній на рис. 4, показано потоки логістичної інформації щодо перевезень місцевих вантажів за участю ВАЗП за варіантом 2 при формуванні на станції ОЛЦ. Ця схема забезпечує безпосередню інформаційну взаємодію АСК ВП УЗ та ІКС місцевої 
роботи i передбачається для районів із досить великими обсягами роботи 3 підприємствами (але недостатніми для формування відправницьких або технічних маршрутів). Регулювання використанням маневрових локомотивів ОЛЦ передбачається на одному 3 АРМів за допомогою даних АРМ ДНЦ, що економічно обгрунтовано, але може призводити до зменшення оперативності прийняття рішень.

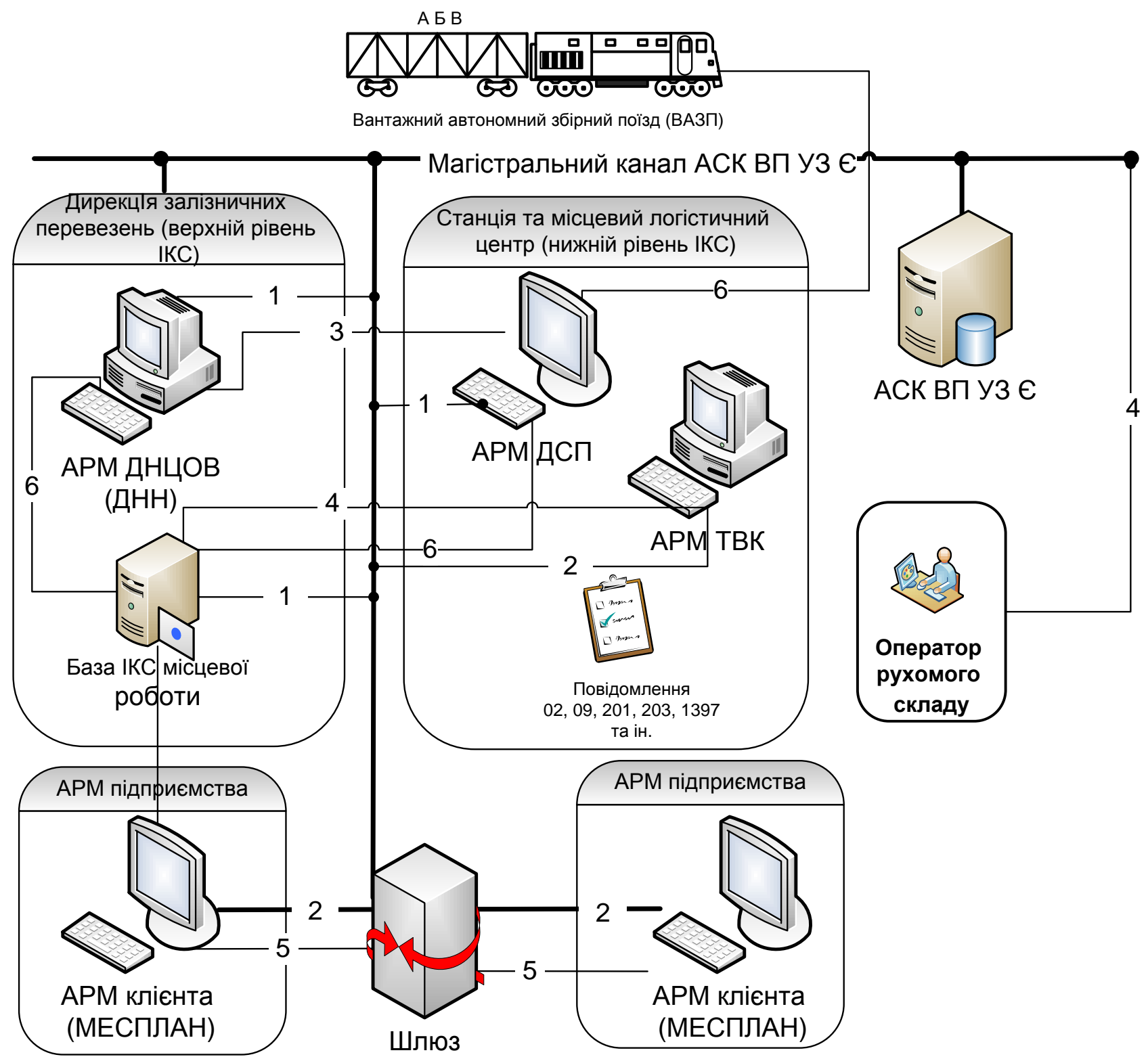

Рис. 3. Схема модулів ІКС місцевої роботи при управлінні перевезеннями вантажів за варіантом 1 - місцевий логістичний центр 


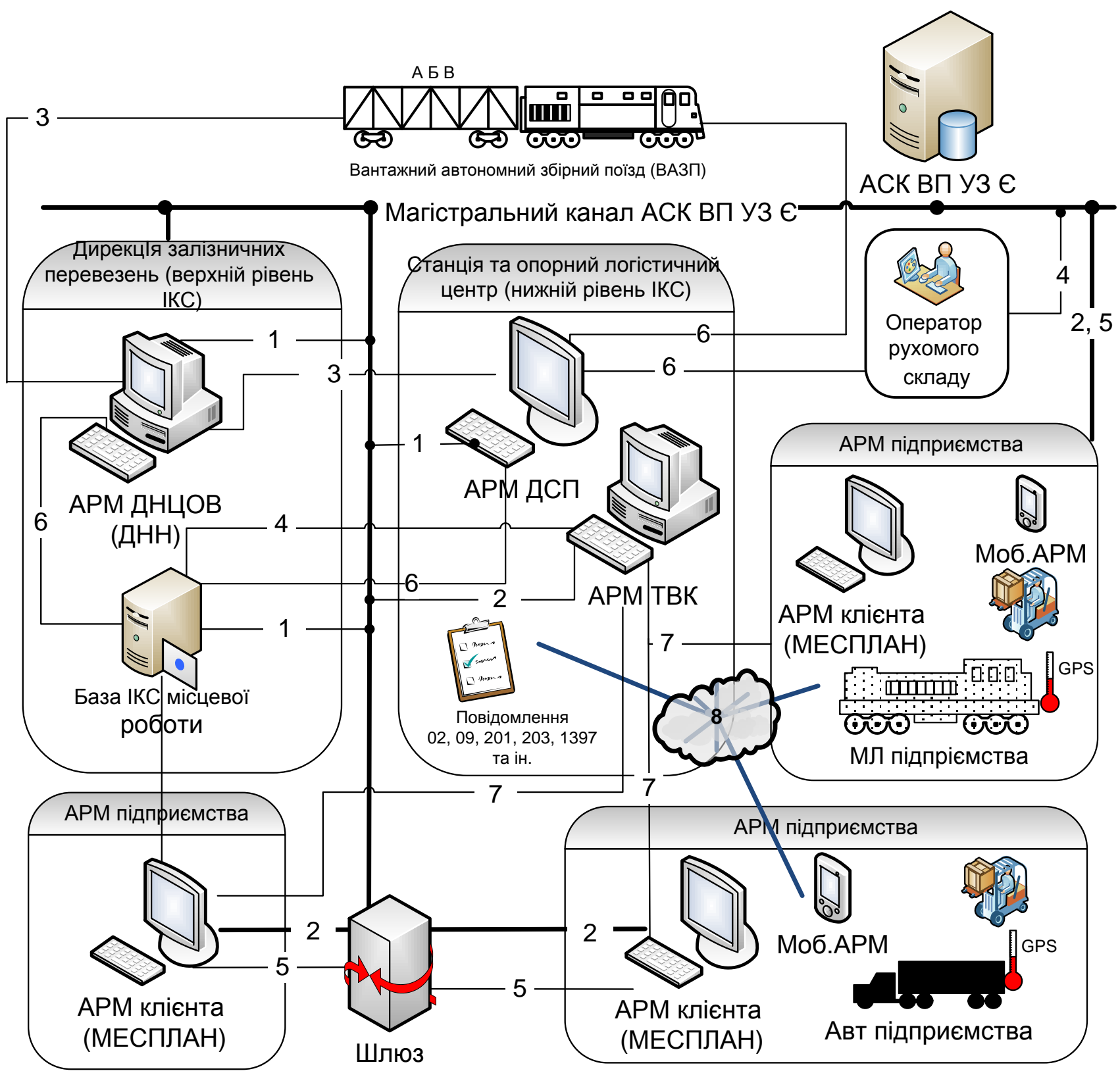

Рис. 4. Схема модулів ІКС місцевої роботи при управлінні перевезеннями вантажів за варіантом 2 - опорний логістичний центр

Стисле пояснення до рис. 4:

інформаційні потоки за призначенням відповідають рис. 3;

інформаційний потік (7) - обмін повідомленнями між АРМ підприємства (АС МЕСПЛАН) та ІКС місцевої роботи 3 метою синхронізації даних та наповненням бази даних АСК ВП УЗ $Є$ інформацією, необхідної для роботи відповідних СППР; інформаційний потік (8) - обмін повідомленнями між стаціонарними елементами ІКС місцевої роботи та мобільними АРМ на підприємствах-прийомоздавальниках, на маневрових локомотивах та на автотранспорті, що знаходяться безпосередньо на під’їних коліях та ОЛЦ. Обмін здійснюється, як правило, 3 допомогою бездротових каналів зв'язку. 
Подальший розвиток IКС місцевої роботи при участі ВАЗП пов'язано із використанням безпаперового документообігу на базі «хмарових» обчислень, «мобільних» АРМ ДСП, товарного касира та прийомоздавальника та застосування GPS - технологій для ідентифікації місцезнаходження рухомого складу.

Техніко-економічні розрахунки 3 визначення оптимальних параметрів місцевої роботи в умовах ІКС запропоновано виконати за удосконаленою методикою, розробленою професором А.О. Смеховим для різних режимів роботи кожного і-го ОЛЦ та k-го МЛЦ. Цільова функція економіко-математичної моделі прийнята для режиму місцевої роботи в умовах визначеної кількості вантажнорозвантажувальних машин $Z$ для ОЛЦ та постійної їх кількості для МЛЦ (визначено наявністю машин у ВАЗП), подач вагонів 3 урахуванням обмеженої кількості маневрових локомотивів (X) і тривалості обслуговування підприємства (Т), виглядає таким чином:

$$
\Phi(Z, X, T)=\sum_{i=1}^{L} \sum_{j=1}^{7} C_{i j}+\sum_{k=1}^{M} \sum_{j=1}^{5} C_{k j} \rightarrow \min
$$

де L, M - відповідно кількість ОЛЦ та МЛЦ на полігоні;

$\mathrm{C}_{1}$ - витрати на амортизацію $\mathrm{i}$ ремонт вантажно-розвантажувальних машин;

$\mathrm{C}_{2}$ - витрати на вагоно-години простою місцевих вагонів при навантаженні i вивантаженні, коли вони надходять на адресу логістичного центру;

$\mathrm{C}_{3}$ - витрати на подачу, розставлення, перестановку, складання i прибирання вагонів на МЛЦ або ОЛЦ окремими групами з урахуванням обмеженої кількості локомотивів;

$\mathrm{C}_{4}$ - витрати на очікування вагонами виконання вантажних операцій (обумовлені режимом роботи підприємств вантажовласників);

$\mathrm{C}_{5}$ - витрати, що зв'язані з очікуванням вагонами вантажних операцій у зв'язку 3 зайнятістю вантажних фронтів іншими вагонами через нерівномірність їх надходження за кількістю або за часом;

$\mathrm{C}_{6}$ - витрати на амортизацію і ремонт вантажно-розвантажувальних колій, при оснащенні ОЛЦ засобами механізації;

$\mathrm{C}_{7} \quad-$ витрати на очікування автомобілями вантажних операцій через зайнятість ОЛЦ іншим автотранспортом.
3 метою оцінки ефективності ІКС місцевої роботи запропоновано використати вихідні дані для визначення оптимальних режимів роботи на полігоні Харківської дирекції залізничних перевезень. Використання ВАЗП у різних технологічних варіантах дозволяе скоротити середній час простою вагонів та тривалість обробки групи вагонів по відправленню $\Delta \mathrm{t}=6,8 \quad$ год. $\quad(16 \%) \quad \mathrm{y}$ порівнянні з фактичним (див. таблицю).

Доцільність впровадження IКC обгрунтовано 3 урахуванням витрат на комп'ютерну техніку та організацію сучасних інформаційних он-лайн каналів. Поряд 3 цим визначено економію від раціонального використання локомотивного та вагонного парків, ефект від можливості оперативного контролю за місцевою роботою та підвищення достовірності прогнозу прибуття вагонів на ОЛЦ та МЛЦ, скорочення обсягів виплат штрафів за неподання вагонів і порушення терміну доставки вантажів i вагонів. 3 урахуванням вищенаведених факторів оцінку терміну окупності ІКС визначено на рівні 4 років. 
Виконання простоїв на Харківській дирекції залізничних перевезень

\begin{tabular}{|c|c|c|}
\hline Період & $\begin{array}{c}\text { Простій під однією вантажною } \\
\text { операцією, год }\end{array}$ & $\begin{array}{c}\text { Простій місцевого вагона, } \\
\text { год }\end{array}$ \\
\hline Січень & 47,39 & 48,38 \\
\hline Лютий & 42,82 & 43,26 \\
\hline Березень & 41,88 & 42,36 \\
\hline Квітень & 43,88 & 44,22 \\
\hline Травень & 42,51 & 43,20 \\
\hline Червень & 35,63 & 36,48 \\
\hline Липень & 38,78 & 39,83 \\
\hline Серпень & 39,81 & 40,92 \\
\hline Вересень & 37,73 & 38,82 \\
\hline Жовтень & 38,05 & 39,11 \\
\hline Листопад & 41,12 & 42,42 \\
\hline Грудень & 46,05 & 47,23 \\
\hline Рік & 40,33 & 42,19 \\
\hline
\end{tabular}

Висновки. Розроблений підхід щодо удосконалення технології місцевої роботи на базі IКC дозволить покращити управління вантажо- та вагонопотоками у процесі використання ВАЗП при взаємодії iз промисловими підприємствами та іншими учасниками транспортного процесу. Синергетичний ефект від впровадження та використання ІКС місцевої роботи буде складатись із:

- підвищення якості та розширення географії транспортного обслуговування вантажовласників, покращення привабливості та конкурентоспроможності залізничного транспорту;
- поліпшення використання рухомого складу у місцевому сполученні;

- вивільнення робочого часу працівників, що здійснюють керування місцевою роботою;

- підвищення технологічної дисципліни та культури керування місцевою роботою на полігоні;

- зниження кількості порушень терміну доставки вантажів у логістичному ланцюгу постачання та зменшення $\mathrm{y}$ перевізника фінансових втрат за рахунок якісного планування перевезень та високого ступеня узгодженості у всіх ланках перевізного процесу.

\section{Список літератури}

1. Козак, В.В. Методологічний підхід щодо створення структури логістичного центру залізниць України [Текст] / Т.В. Бутько, Д.В. Ломотько, В.В. Козак, В.М. Кулешов // Залізничний транспорт України. - 2007. - № 1. - С. 29-33.

2. Панкратов, В.I. Удосконалення технології роботи залізничного транспорту незагального користування на базі інформаційно-керуючої системи [Текст] / B.I. Панкратов // Зб. наук. праць. - Харків: УкрДАЗТ, 2007. - Вип. 85. - С.12-24.

3. Левківський, О.П. Вибір стратегії формування транспортного процесу різних видів транспорту на базі логістичних принципів [Текст] / О.П. Левківський // Інформаційнокеруючі системи на залізничному транспорті. - 2008. - № 4. - С. 19-20. 
4. Гаджинский, А.М. Основы логистики [Текст]: учеб. пособие / А.М. Гаджинский. М.: ИВЦ «Маркетинг», 1995. - 248 с.

5. Ломотько, Д.В. Методологія формування інтелектуальної транспортної системи на залізничному транспорті [Текст] / Д.В. Ломотько, Т.В. Бутько // Сб. науч. трудов SWorld. Материалы межд. науч.-практ. конф. «Современные направления теоретических и прикладных исследований 2012». - Одесса: Куприенко, 2012. - Вып. 1. - Т. 2. - С. 45-46.

6. Vorkut, T.A. Haulage Company ATP: logistics decisions for restructuring [Text]/ T.A. Vorkut // Oak Brook, IL: CLM - 2000. - 44 p.

7. Данько, M.I. Удосконалення планування перевізних процесів на залізничному транспорті методами нечіткої логіки [Текст] / M.I. Данько // Новини науки Придніпров'я. 2005. - № 2. - С. 55-58.

8. Губенко, В.К. Оптимизация оперативно-календарного плана доставки многономенклатурных мелкопартионных грузов на промышленных предприятиях [Текст] / В.К. Губенко, Г.Ф.Бабушкин, А.Ф.Кузькин // Вісник Приазовського державного технічного університету: зб. наук. праць.- 2001.- № 11.- С. 273-276.

9. Мкртичьян, Д.І. Перспективи удосконалення технології розвозу місцевого вантажу на залізничному транспорті [Текст] / Д.І. Мкртичьян, Д.В. Каньовська // Зб. наук. праць. Харків: УкрДАЗТ. - Вип. 124. - С. 95-99.

10. Жуковицкий, И.В. Метод интерактивной динамической оптимизации распределения локомотивов для работы в поездах на основе оценки рисков [Текст] / И.В. Жуковицкий, А.Б. Устенко, О.Л. Зиненко // Інформаційно-керуючи системи на залізничному транспорті. - 2006. - № 4. - С. 86 - 91 .

11. Шиш, В.О. Проблеми та шляхи оптимізації оперативного регулювання вагонних парків на мережі залізниць [Текст] / В.О. Шиш, П.О. Яновський // Залізн. трансп. України. 2007. - № 1. - C. 54-58.

Ключові слова: транспортний процес, логістика, залізничний транспорт, інформаційно-керуюча система, вантажні перевезення, автономний поїзд.

\section{Анотаціï}

Розроблено комплекс задач та структуру логістичної інформаційно-керуючої системи місцевої роботи залізничного транспорту. Вона враховує специфіку характерних технологічних схем взаємодії станцій примикання та під'їзних колій підприємств. Запропоновано створити систему опорних та місцевих логістичних центрів 3 метою ефективного обслуговування вантажовласників за допомогою вантажних автономних збірних поїздів. Визначено основні підсистеми запропонованої керуючої системи в умовах раціоналізації планування обробки місцевих вантажів.

Разработан комплекс задач и структура логистической информационно-управляющей системы местной работы железнодорожного транспорта. Она учитывает специфику характерных технологических схем взаимодействия станций примыкания и подъездных путей предприятий. Предложено создать систему опорных и местных логистических центров с целью эффективного обслуживания грузовладельцев за счет грузовых автономных сборных поездов. Определены основные подсистемы предложенной управляющей системы в условиях рационализации планирования обработки местных грузов. 
A complex of tasks and a structure of logistical informational and managerial system of local railway transport work are developed. It consideres specificity of characteristic technological schemes of cooperation of adjacent stations and approaching lines of enterprises. It is offered to create a system of base and local logistical centers with the view of effective service for freight owners by means if autonomous collecing freight trains. The main subsystems of osuggested managerial system in conditions of planning local freghts handling rationalization are specified. 